\title{
Implementasi Model Problem Based Learning Berbantu Lego dalam Meningkatkan Hasil Belajar Matematika SD
}

\author{
Mila Pertiwi ${ }^{1 *}$, A.Y Soegeng Ysh ${ }^{2}$, Filia Prima Artharina ${ }^{3}$ \\ ${ }^{123}$ Jurusan Pendidikan Guru Sekolah Dasar, FIP,Universitas PGRI Semarang, Indonesia
}

\author{
A R T I C LEINFO \\ Article history: \\ Received 18 February \\ 2019 \\ Received in revised form \\ 20 March 2019 \\ Accepted 20 April 2019 \\ Available online 20 May \\ 2019 \\ Kata Kunci: \\ Problem Based Learning, \\ Hasil Belajar, Matematika \\ Keywords: \\ Problem Based Learning, \\ Learning Outcomes, \\ Mathematics
}

\begin{abstract}
A B S T R A K
Implementasi Model Problem Based Learning berbantu Media Lego dalam Meningkatkan Hasil Belajar Matematika SD. Tujuan penelitian ini adalah untuk mengetahui implementasi model problem based learning berbantu lego terhadap hasil belajar matematika kelas IV SDN Gabus 01 Gabus Pati Tahun Pelajaran 2018/2019. Jenis penelitian ini adalah kuantitatif dalam bentuk true experimental design, dengan rancangan pretest-posttest control groub design. Teknik sampling dalam penelitian ini adalah simple random sampling. Jenis sampel yang digunakan adalah kelas IVA dan IVB. Teknik pengumpulan data dilakukan dengan menggunakan wawancara, kuesioner, observasi, dan tes. Hasil belajar siswa dilihat dari rata-rata nilai pretest yaitu pada kelas kontrol 64,25 menjadi 71,25 pada nilai posttest. Sedangkan pada kelas eksperimen dilihat dari rata-rata nilai pretest yaitu 54,75 menjadi 80,25 pada nilai posttest. Berdasarkan hasil uji $t$ diketahui thitung lebih besar daripada $t_{\text {tabel }}(2,394<2,023)$ maka $\mathrm{H}_{0}$ ditolak dan $\mathrm{H}_{\mathrm{a}}$ diterima. Kesimpulanya bahwa implementasi model problem based learning mampu meningkatkan hasil belajar matematika SD.
\end{abstract}

\section{A B S T R A C T}

Implementation of Lego Media-assisted with Problem Based Learning Model in Improving Elementary Mathematics Learning Outcomes. The purpose of this study was to determine the implementation of Lego-assisted problem based learning models on the fourth grade mathematics learning outcomes at SDN Gabus 01 Pati 2018/2019 Academic Year. This type of research was quantitative in form of true experimental design, with a pretest-posttest control group design. The sampling technique in this study was simple random sampling. The type of sample used IVA and IVB. Data collection techniques were carried out using interviews, questionnaires, observations, and tests. Student learning outcomes can be seen from the average of the pretest in control class was 64.25 to 71.25 at the posttest. The experimental class, the average pretest was 54.75 to 80.25 at posttest. Based on $\mathrm{t}$ test results was greater than $\mathrm{t}_{\text {table }}(2,394<2,023)$ then $\mathrm{H}_{0}$ is rejected and $\mathrm{H}_{\mathrm{a}}$ accepted. The conclusion was that the implementation of the problem based learning model was able to improve elementary school mathematics learning outcomes .

Copyright (C) Universitas Pendidikan Ganesha. All rights reserved.

\footnotetext{
${ }^{1}$ Corresponding author.

E-mail addresses: aksarapertiwi@gmail.com (Mila Pertiwi)
} 


\section{Pendahuluan}

Abad ke-21 dikenal dengan masa pengetahuan (knowledge age), dimana semua upaya pemenuhan kebutuhan hidup dalam berbagai konteks berbasis pada pengetahuan. Mukhadis dalam Wijaya, Sudjimat, Nyoto (2016: 264) mengemukakan bahwa upaya pemenuhan kebutuhan bidang pendidikan berbasis pengetahuan (knowledge based education), pengembangan ekonomi berbasis pengetahuan (knowledge based economic), dan pengembangan dan pemberdayaan masyarakat berbasis pengetahuan (knowledge based social empowering), dan pengembangan dalam bidang indutri pun berbasis pengetahuan (knowledge based industry).

Perancangan abad 21 dilakukan pemerintah melalui Kurikulum 2013 yang berbasis pada siswa. Pembelajaran ini. menuntut pada penerapan kemampuan 4C (Critical Thinking, Communication, Colaboration, Cretivity). Hal ini diharapkan bukan hanya pengubahan model pengajaran untuk mencapai kualitas pengajaran yang tinggi dalam setiap mata pelajaran bagi pendidik dalam hal ini guru. Akan tetapi peran dan tanggungjawab non formal dalam membiasakan anak-anak dalam menerapkan 4C dalam keseharian.

Menurut Azmi (2016) Pendidikan merupakan usaha untuk membantu peserta didik mengembangkan seluruh potensinya (hati, pikir, rasa, dan karsa, serta raga) untuk menghadapi masa depan [1]. Hal ini sejalan dengan tujuan pendidikan yang terdapat dalam UndangUndang Sistem Pendidikan Nasional Nomor 20 tahun 2003 menyatakan bahwa, tujuan Pendidikan Nasional adalah untuk berkembangnya potensi peserta didik agar menjadi manusia yang beriman dan bertakwa kepada Tuhan Yang Maha Esa, berakhlak mulia, sehat, berilmu, cakap, kreatif, mandiri, dan menjadi warga negara yang demokratis serta bertanggung jawab. Untuk mencapai tujuan pendidikan tersebut, tentu tidak terlepas dari proses belajar. Proses belajar terjadi karena adanya intraksi antara seseorang dengan lingkungannya [2]. Dalam proses belajar diharapkan dapat mencerminkan tiga aspek dalam kegiatan pembelajaran, yaitu aspek sikap, pengetahuan dan keterampilan. Dikembangkangkannya kurikulum baru, kurikulum 2013, dalam sistem pendidikan nasional, mengupayakan ketiga aspek dalam tujuan pendidikan nasional dapat dilaksanakan dalam setiap proses pembelajaran. Kurikulum 2013 menurut Kunandar (2014: 34) menganut pada pembelajaran yang dilakukan guru (taught curriculum) dalam bentuk proses yang dikembangkan berupa kegiatan pembelajaran di sekolah, di kelas, dan di masyarakat dan pengalaman belajar langsung peserta didik (learnerd curriculum) sesuai dengan latar belakang, karakteristik, dan kemampuan awal peserta didik.

Salah satunya mata pelajaran dalam Kurikulum 2013 yakni matematika yang dituntut dalam pembentukanya melalui pembelajaran yang berkelanjutan dimulai dari meningkatkan pengetahuan metode-metode matematika, dilanjutkan dengan keterampilan menyajikan suatu permasalahan secara matematis dan menyelesaikannya yang bermuara pada kemampuan berpikir logis, perkembangan nalas, kritis dan cermat serta bersikap terbuka dan objektif dalam menghadapi permasalahan yang ada.

Secara umum, pembelajaran matematika bertujuan agar peserta didik memiliki kemampuan matematika. Kemampuan matematika merupakan bagian dari keterampilan yang harus dimiliki peserta didik terutama dalam pengembangan penalaran, komunikasi, dan pemecahan masalah (problem solving) yang akan dihadapi dalam kehidupan peserta didik sehari-hari.

Berdasarkan informasi yang didapatkan melalui wawancara yang dilakukan peneliti kepada guru kelas IV SDN Gabus 01 Gabus Pati menunjukkan bahwa ada beberapa permasalahan yang terjadi yaitu konsentrasi anak dalam proses pembelajaran yang rendah. Hal ini dikarenakan penggunaan model yang kurang sesuai dengan kebutuhan dalam proses pembelajaran.

Hal ini dibuktikan dengan model yang digunakan masih model yang bersifat konvensional. Menurut Ibrahim (2017) model pembelajaran merupakan desain kerangka konseptual yang tersusun secara sistematis dalam mengorganisasikan pengalaman belajar, mencerminkan penerapan suatu pendekatan, metode dan teknik pembelajaran sekaligus dan berfungsi sebagai pedoman bagi guru dalam merencanakan dan melaksanakan kegiatan belajar mengajar. model pembelajaran konvensional merupakan pembelajaran yang terpusat pada guru, mengutamakan hasil bukan proses, siswa ditempatkan sebagai objek dan bukan subjek pembelajaran sehingga siswa sulit untuk menyampaikan pendapatnya. Selain itu metode yang digunakan tidak terlepas dari ceramah, pembagian tugas dan latihan sebagai bentuk pengulangan dan pendalaman materi ajar. Menurut Dewi (2018) keberhasilan dunia pendidikan tidak terlepas dari penggunaan metode pembelajaran. Metode pembelajaran (instruction method) merupakan akumulasi konsep-konsep mengajar (teaching) dan konsep belajar (learning). Keduanya merupakan perpaduan dalam sistem pembelajaran yang melibatkan siswa, tujuan, materi, fasilitas, prosedur, alat atau media yang digunakan. Arti penting dari metode pembelajaran sangat tergantung dari kemodernan dan konvensional penerapannya. Beberapa hasil penelitian dalam penggunaan metode pembelajaran yang berhasil di dalam mewujudkan tujuan pendidikan adalah pembelajaran yang modern 
dan konvensional. Jenis metode pembelajaran yang digunakan dalam belajar sangat tergantung pada tuntutan kebutuhan, keinginan, harapan dan aktivitas belajar yang dapat dilakukan secara tutorial, ceramah, resistensi, diskusi, kegiatan laboratorium dan pekerjaan rumah. Cara-cara ini merupakan metode yang modern dan konvensional bila dipadukan dan diramu menjadi sumber kreativitas dan produktivitas belajar yang menghasilkan kemodernan dan konvensional dari metode-metode yang ada. Menurut Dewina (2017) dalam proses PBL, kegiatan yang dilakukan oleh guru adalah menghadirkan permasalahan dunia nyata di dalam kelas yang tentunya berkaitan dengan materi atau indikator yang akan dicapai, sehingga siswa akan terlibat langsung dalam memecahkan masalah yang ada. Menurut Fauziah (2018) model PBL merupakan model pembelajaran yang menyajikan masalah untuk diselesaikan siswa melalui diskusi kelompok sehingga siswa yang menjadi pusat pada proses pembelajaran bukan lagi guru. Model PBL membuat pembelajaran lebih bermakna dengan masalah yang disajikan, sehingga siswa dapat menemukan sendiri konsep matematika dari hasil diskusi yang mereka lakukan.

Selain itu dalam proses pembelajaran, guru masih menggunakan media gambar, sehingga siswa lebih asyik bermain sendiri. Kurangnya penguasaan siswa dalam menyelesaikan soal yang diberikan terutama soal pemecahan masalah matematika dan masih sekitar 60 sampai $70 \%$ siswa belum mampu berpikir kritis. Selain itu siswa masih jarang menerima soal soal yang mengacu pada proses berpikir kritis. Selain hal tersebut, permasalahan lain yang terjadi pada siswa kelas IV SDN Gabus 01 Gabus Pati adalah nilai pelajaran matematika yang rendah dan di bawah dari kriteria ketuntasan minimum (KKM) yang ditetapkan yaitu 75 .

Oleh karena itu peneliti mencoba memberikan alternatif dalam proses pembelajaran sesuai dengan masalah yang sedang di hadapi yakni dengan menguji cobakan model pembelajaran problem based learning dengan berbantu lego. Dengan adanya alternatif model yang pembelajaran problem based learning dengan berbantu lego diharapkan dapat memberikan solusi terhadap kemampuan memecahkan masalah dan meningkatkan hasil belajar peserta didik.

Tujuan penulisan artikel ini adalah untuk mendeskripsikan hasil belajar matematika kelas IV melalui model problem based learning berbantu media lego. Menurut Sianturi (2018) dalam model Problem Based Learning (PBL), fokus pembelajaran ada pada masalah yang dipilih sehingga siswa tidak saja mempelajari konsep-konsep yang berhubungan dengan masalah tetapi juga metode ilmiah untuk memecahkan masalah tersebut. Oleh sebab itu, siswa tidak saja harus memahami konsep yang relevan dengan masalah yang menjadi pusat perhatian tetapi juga memperoleh pengalaman belajar yang berhubungan dengan keterampilan menerapkan metode ilmiah dalam pemecahan masalah dan menumbuhkan pola berpikir kritis.

Adapun langkah-langkah problem based learning (dalam Hosnan, 2016: 301) adalah sebagai berikut: (1) orientasi siswa dalam masalah; guru menjelaskan tujuan pembelajaran, menjelaskan logistik yang dibutuhkan, memotivasis siswa agar terlibat pada aktivitas pemecahan masalah yang dipilih; (2) mengorganisasi siswa untuk belajar; guru membantu siswa mendefinisikan dan mengorganisasikan tugas belajar yang menghubungkan dengan masalah tersebut; (3) membimbing penyelidikan individual dan kelompok; guru mendorong siswa untuk mengumpulkan informasi yang sesuai, pelaksanaan eksperimen untuk mendapatkan penjelasan dan pemecahan masalahnya; (4) mengembangkan dan menyajikan hasil karya; guru membantu siswa merencanakan dan menyiapkan karya yang sesuai seperti laporan, video, dan model serta membantu berbagai tugas dengan temannya; (5) menganalisis dan mengevaluasi proses pemecahan masalah; guru membantu siswa melakukan refleksi atau evaluasi terhadap penyelidikan dan proses-proses yang mereka gunakan.

Kekurangan problem based learning menurut Shoimin (2014: 132) antara lain: (1) model problem based learning tidak dapat diterapkan untuk setiap materi pembelajaran, ada bagian guru berperan akif dalam menyajikan materi; (2) model problem based learning lebih cocok untuk pembelajaran yang menuntut kemampuan tertentu yang kaitannya dengan pemecahan masalah; (3) dalam kelas yang memiliki tingkat keragaman yang tinggi akan terjadi kesulitan dalam pembagian tugas.

\section{Metode}

Jenis penelitian yang digunakan adalah kuantitatif dalam bentuk true experimental design rancangan pretest-posttest control groub design. Sampel yang digunakan dalam penelitian ini adalah siswa kelas IVA dan IVB SDN Gabus 01 Gabus Pati. Teknik sampling yang digunakan yaitu simple random sampling. Teknik pengumpulan data yang dilakukan dengan menggunakan wawancara, kuesioner, observasi dan tes. Teknik analisis data menggunakan uji normalitas awal dengan data pretest dan uji homogenitas awal dan uji normalitas akhir posttest dan homogenitas akhir. Uji hipotesis yang digunakan pada penelitian ini adalah uji $t$ untuk membandingkan hasil data posttest. Sedangkan untuk keefektifan digunakan ketuntasan belajar klasikal dan ketuntasan belajar individu. 


\section{Hasil dan Pembahasan}

Penelitian ini menggunakan teknik pretest-posttest yang bertujuan untuk mengambil hasil belajar siswa. Pretest merupakan tes yang dilakukan untuk mengetahui kemampuan awal siswa sebelum mendapatkan perlakuan model problem based learning berbantu lego. Sedangkan posttest merupakan tes yang dilakukan untuk mengetahui kemampuan siswa setelah mendapat perlakuan model problem base learning berbantu lego.

Sesuai dengan langkah yang digunakan dalam penelitian ini adalah model problem based learning, yang pertama orientasi siswa dalam masalah; guru menjelaskan tujuan pembelajaran, menjelaskan logistik yang dibutuhkan, memotivasis siswa agar terlibat pada aktivitas pemecahan masalah yang dipilih, Kedua, mengorganisasi siswa untuk belajar; guru membantu siswa mendefinisikan dan mengorganisasikan tugas belajar yang menghubungkan dengan masalah tersebut, Ketiga, membimbing penyelidikan individual dan kelompok; guru mendorong siswa untuk mengumpulkan informasi yang sesuai, pelaksanaan eksperimen untuk mendapatkan penjelasan dan pemecahan masalahnya, Keempat, mengembangkan dan menyajikan hasil karya; guru membantu siswa merencanakan dan menyiapkan karya yang sesuai seperti laporan, video, dan model serta membantu berbagai tugas dengan temannya, dan Kelima, menganalisis dan mengevaluasi proses pemecahan masalah; guru membantu siswa melakukan refleksi atau evaluasi terhadap penyelidikan dan proses-proses yang mereka gunakan. Berikut data hasil pretest-posttest matematika siswa kelas IV SDN Gabus 01 Gabus Pati.

Sebelum peneliti memberikan perlakuan (treatment) pada kelas eksperimen, terlebih dahulu data awal nilai siswa baik nilai untuk kelas eksperimen maupun nilai awal kelas kontrol. Nilai awal ini diambil dari hasil nilai pretest kemudian dihitung nilai rata-ratanya. Hasil nilai awal kelas kontrol dan kelas eksperimen dapat dilihat pada Tabel 1 sebagai berikut:

Tabel 1. Nilai Pretest Kelas Kontrol dan Kelas Eksperimen

\begin{tabular}{lcc}
\hline \multicolumn{1}{c}{ Kriteria } & Kelas Kontrol & Kelas Eksperimen \\
\hline Rata-rata & 64,25 & 54,75 \\
Nilai Tertinggi & 85 & 75 \\
Nilai Terendah & 45 & 35 \\
\hline
\end{tabular}

Berdasarkan Tabel 1 diketahui bahwa pada kelas kontrol nilai tertinggi pada kelas kontrol 85, nilai terendah pada kelas kontrol 45 dengan rata-rata 64,25. Sedangkan pada kelas eksperimen nilai tertinggi diperoleh 75 dan nilai terendah diperoleh sebesar 35 , dengan nilai rata-rata sebesar 54,75. Berikutnya hasil pretest dijadikan sebagai pembanding untuk mengetahui kemampuan awal siswa SDN Gabus 01 Gabus Pati.

Berdasarkan hasil rata-rata pretest kelas eksperimen dan kelas kontrol hanya selisih 9,5. Kelas kontrol lebih tinggi 9,5 sedangkan kelas eksperimen lebih rendah 9,5 dapat disimpulkan kemampuan awal siswa SDN Gabus 01 Gabus Pati sama.

Selanjutnya nilai yang digunakan dalam penelitian ini adalah dari hasil posttest dari kelas eksperimen dan kelas kontrol. Kelas kontrol dalam proses pembelajaran matematika menggunakan model problem based learning berbantu kertas. Sementara kelas eksperimen dalam proses pembelajaran matematika sama sama menggunakan model problem based learning namun medianya yang berbeda yakni menggunakan lego. Dari perbedaan proses pembelajaran antara kelas kontrol dengan kelas eksperimen terletak pada proses pemecahan masalahnya yakni dari media yang digunakan dalam model tersebut. Perbedaan perlakuan yang diberikan antara kedua kelas tersebut memberikan dampak hasil proses pembelajarannya dibandingkan anatar kelas eksperimen dan kelas kontrol untuk mengetahui adanya perbedaan hasil belajar kelas kontrol dengan kelas eksperimen. Berikut ini adalah nilai kognitif atau posttest kelas kontrol dan kelas eksperimen:

Tabel 2. Nilai Posttest Kelas Kontrol dan Kelas Eksperimen

\begin{tabular}{lll}
\hline Kriteria & Kontrol & Eksperimen \\
\hline Rata-rata & 71,25 & 80,25 \\
Nilai Terendah & 40 & 55 \\
Nilai Tertinggi & 90 & 95 \\
\hline
\end{tabular}

Sumber: Analisis Hasil Posttest 2019 
Berdasarkan Tabel 2 nilai posttest di atas diketahui bahwa hasil posttest diatas diperoleh nilai ratarata kelas kontrol 71,25 dan nilai rata-rata pada kelas eksperimen 80,25. Selisih nilai rata-rata kelas kontrol dan kelas eksperimen sebanyak 9. Adapun perolehan nilai terendah pada kelas kontrol 40 dan nilai terendah kelas eksperimen adalah 55, sedangkan nilai tertinggi kelas kontrol 90 dan nilai tertinggi kelas eksperimen sebesar 95. Nilai posttest tersebut digunakan untuk mengetahui apakah ada perbedaan keefektifan model problem based learning berbantu lego pada mata pelajaran matematika khususnya materi pecahan senilai kelas IV pada kelas eksperimen dan kelas kontrol dengan model problem based learning dengan menggunakan kertas kelas IV pada kelas kontrol dengan pelajaran dan materi yang sama.

Berdasarkan diagram 2 di atas diketahui bahwa kelas kontrol dan kelas eksperimen telah mencapai ketuntasan dari kriteria ketuntasan minimal (KKM) yang telah ditetapkan oleh SDN Gabus 01 Gabus Pati tahun pelajaran 2018/2019 yaitu 75. Nilai kelas eksperimen lebih tinggi sebesar 9 dari kelas kontrol. Berikut ini presentase nilai pretest-posttest eksperimen dan kontrol berdasarkan nilai pretets dan nilai posttest kelas eksperimen dan kelas kontrol:

Tabel 3. Persentase Nilai Pretest-Posttest Kelas Kontrol dan Kelas Eksperimen

\begin{tabular}{|c|c|c|}
\hline Keterangan & Tuntas & Tidak Tuntas \\
\hline Pretest Kontrol & $30 \%$ & $70 \%$ \\
\hline Pretest Eksperimen & $5 \%$ & $95 \%$ \\
\hline Posttest Kontrol & $60 \%$ & $40 \%$ \\
\hline Posttest Eksperimen & $75 \%$ & $25 \%$ \\
\hline
\end{tabular}

Sumber: Hasil Analisis Nilai Pretest-Posttest Kelas Kontrol dan Eksperimen

Berdasarkan Tabel 3 dapat diketahui bahwa terdapat peningkatan ketuntasan hasil belajar baik kelas kontrol maupun kelas eksperimen. Peningkatan ketuntasan kelas kontrol dari presentase nilai pretest 30\% menjadi nilai posttest dengan presentase sebesar $60 \%$ meningkat sebesar 30\%. Peningkatan nilai untuk kelas eksperimen 5\% untuk nilai pretest ke 75\% untuk nilai posttest. Sedangkan untuk presentasi tidak tuntas dari kelas kontrol sebesar $70 \%$ untuk nilai pretest dan $40 \%$ untuk nilai posttest. Berarti presentasi nilai tidak tuntasnya menurun sebesar 30\%. Presentase tidak tuntas pada kelas eksperimen juga menurun sebesar 70\% dari 95\% untuk nilai pretest menjadi 25\% untuk nilai posttest.

Berdasarkan perbedaan ketuntasan hasil belajar siswa antara ketuntasan hasil posttest, diketahui bahwa ketuntasan belajar posttest kelas eksperimen lebih tinggi dibandingkan ketuntasan belajar posttest pada kelas kontrol.

Selain mengetahui nilai kognitif yakni berupa posttest, selanjutnya nilai yang diketahui dalam penelitian ini adalah dari nilai sikap atau afektif selama proses pembelajaran dari kelas kontrol dan kelas eksperimen. Kelas kontrol dalam proses pembelajaran matematika menggunakan model problem based learning berbantu media konvensional dalam pembelajaran ini menggunakan media kertas saja. Sementara kelas eksperimen dalam proses pembelajaran matematika menggunakan model problem based learning berbantu lego dengan mata pelajaran dan materi yang sama dengan kelas kontrol.

Perbedaan perlakuan terhadap proses pemecahan masalah yang diberikan memperoleh dampak hasil nilai afektif yang berbeda antara kelas kontrol dan kelas eksperimen. Penilaian afektif siswa sendiri diperhitungkan berdasarkan kriteria penilaian yang sudah ditetapkan dalam Rencana Pelaksanaan Pembelajaran (RPP) yang telah ditetapkan oleh peneliti. Sikap yang diharapkan dapat tercapai dalam penelitian ini yaitu sikap teliti, rasa ingin tahu, tanggungjawab, dan juga percaya diri. Berikut ini nilai afektif yang didapat oleh siswa:

Tabel 4. Nilai Afektif Kelas Kontrol dan Kelas Eksperimen

\begin{tabular}{lccc}
\hline & Disiplin & Tanggungjawab & Percaya diri \\
\hline PMB 1 Kontrol & 77,5 & 75 & 72,5 \\
PMB 2 Jontrol & 78,9 & 82,5 & 80 \\
PMB 1 Kontrol & 70 & 85 & 82,5 \\
PMB 2 Eksperimen & 87,5 & 83 & 85 \\
\hline
\end{tabular}

Berdasarkan Tabel 4 nilai afektif di atas diketahui bahwa kelas kontrol selama 2 kali pembelajaran yang telah dilaksanakan mendapatkan perolehan nilai rata-rata kelas kontrol pada pembelajaran 1 dengan indikator disiplin memperoleh nilai 77,5 dan pada pembelajaran 2 memperoleh nilai 78,9 dengan rata-rata 
nilai indikator disiplin kelas kontrol yaitu 78,2. Penilaian afektif pada kelas kontrol berikutnya yaitu pada indikator tanggungjawab diperoleh nilai 75 untuk pembelajaran 1 dan nilai 82,5 untuk pembelajaran 2 dengan nilai rata-rata indikator tanggungjawab 78,75. Penilaian afektif juga dilakukan pada kelas eksperimen. pembelajaran 1 pada indikator disiplin memperoleh nilai 70 dan pada pembelajaran 2 memperoleh nilai 87,5 dengan nilai rata-rata 78,75 . Penilaian indikator kelas eksperimen selanjutnya yaitu pada indikator tanggungjawab dengan nilai 85 pada pembelajaran 1 dan 83 pada pembelajaran 2 dengan nilai rata-rata 84. Indikator percaya diri pada kelas eksperimen memeproleh nilai 82,5 pada pembelajaran 1 dan nilai 85 pada pembelajaran 2 serta diperoleh nilai rata-rata 83,75.

Sedangkan KKM yang harus dicapai yaitu 75 sehingga dapat dilihat bahwa kelas eksperimen mencapai nilai afektif lebih baik daripada kelas kontrol.

Selain mengetahui nilai kognitif dan afektif, selanjutnya nilai yang diketahui dalam penelitian ini adalah dari nilai psikomotorik atau ketrampilan selama proses pembelajaran dari kelas eksperimen dan kelas kontrol. Sebelum mendapat nilai psikomotorik siswa diberikan proses pembelajaran kelas kontrol selama 2 kali pertemuan dan kelas eksperimen 2 kali pertemuan. Kelas kontrol dalam proses pembelajaran matematika menggunakan model problem based learning dengan media kertas. Sementara kelas eksperimen dalam proses pembelajaran matematika menggunakan model problem based learning berbantu media lego. Perbedaan perlakuan yang diberikan antara kedua kelas tersebut memberikan dampak hasil nilai afektif yang berbeda antara kelas kontrol dan kelas eksperimen. Penilaian psikomotorik siswa sendiri diperhitungkan berdasarkan kriteria penilaian yang sudah ditetapkan dalam Rencana Pelaksanaan Pembelajaran (RPP) yang telah ditetapkan oleh peneliti. Berikut ini nilai psikomotorik yang didapat oleh siswa kelas kontrol dan kelas eksperimen.

Tabel 5. Nilai Psikomotorik Kelas Kontrol dan Kelas Eksperimen

\begin{tabular}{lcccc}
\hline & BK & ML & MK & MHK \\
\hline PMB 1 Kontrol & 73,75 & - & 72,5 & 73,75 \\
PMB 2 Kontrol & 78,75 & - & 83,75 & 78,75 \\
PMB 1 Eks & 78,75 & 86 & - & 80 \\
PMB 2 Eks & 90 & 87,5 & - & 83,75 \\
\hline
\end{tabular}

Keterangan:

$\begin{array}{ll}\text { BK } & =\text { berpikir kritis } \\ \text { ML } & =\text { mengaplikasikan lego } \\ \text { MK } & =\text { mengaplikasikan kertas } \\ \text { MHK } & =\text { mengkomunikasikan hasil kerja }\end{array}$

Berdasarkan Tabel 5 nilai psikomotorik di atas diketahui bahwa kelas kontrol selama 2 kali pembelajaran yang telah dilaksanakan mendapatkan perolehan nilai rata-rata indikator berpikir kritis pembelajaran 1 memeproleh nilai 73,75 dan pembelajaran 2 memperoleh nilai 78,75 dengan rata-rata 76,25. Penilaian indikator selanjutnya yaitu mengaplikasikan kertas dengan nilai pembelajaran 1 yaitu 72,5 dan pembelajaran 283,75 dengan nilai rata-rata 78,2. Penilaian indikator mengkomunikasikan hasil kerja pada pembelajaran 1 yaitu 73,75 dan pembelajaran 2 yaitu 78,75 dengan rata-rata 76,3. Sedangan pada kelas eksperimen terdapat 3 (tiga) indikator yang perlu dinilai yang pertama adalah indikator berpikir kritis dengan rata-rata 84,4 pada pembelajaran 1 diperoleh nilai 78,75 dan pembelajaran 2 memperoleh nilai 90 . Indikator penilai kedua yaitu mengaplikasikan lego dengan nilai rata-rata 86,25 pada pembelajaran 1 diperoleh nilai 85 dan pemeblajaarn 2 diperoleh nilai 87,5. Indikator penilaian ketiga yaitu mengkomunikaiskan hasil kerja dengan rata-rata 83,75 pada pembelajaran 1 diperoleh nilai 80 dan pada pembelajaran 2 diperoleh nilai 87,5. KKM yang harus dicapai sebesar 75 sehingga dapat dilihat bahwa kelas eksperimen mencapai nilai afektif lebih baik daripada kelas kontrol.

Kesimpulan pada diagram tersebut adalah ada perbedaan hasil penilaian yang berbeda proses pemecahan masalah yakni terletak pada media yang digunakan. Kelas kontrol menggunakan model problem based learning berbantu media kertas. Dengan kelas eksperimen menggunakan model problem based learning berbantu lego.

\section{Simpulan dan Saran}

Berdasarkan data hasil penelitian, analisis, dan pembahasan hasil penelitian, maka peneliti membuat kesimpulan bahwa implementasi model problem based learning berbantu lego mampu 
meningkatkan hasil belajar matematika siswa kelas IV SD Gabus 01 Gabus Pati. Hal ini dapat dibuktikan dengan uji hipotesis dengan menggunakan uji $t$ diperoleh $t_{\text {hitung }}=2,394$. Kemudian harga $t_{\text {hitung }}$ dibandingkan dengan harga $t_{\text {tabel }}<t_{\text {tabel }}$ ditentukan dengan $d k=n_{1}+n_{2}-2=38$ dan taraf $\alpha=0,05$ adalah 2,394. Berdasarkan kriteria pengujian bahwa $\mathrm{H}_{\mathrm{a}}$ ditolak dan $\mathrm{H}_{0}$ diterima jika $\mathrm{t}_{\text {hitung }}$ lebih kecil dari $\mathrm{t}_{\text {tabel. }}$ Ternyata didapati $t_{\text {hitung }}$ lebih besar dari $t_{\text {tabel }}$ yaitu $2,394<2,023$. Maka dapat disimpulkan bahwa $\mathrm{H}_{\mathrm{a}}$ ditolak dan $\mathrm{H}_{0}$ diterima, maka penggunaan model problem based learning berbantu lego lebih efektif daripada model problem based learning berbantu kertas.

Ketuntasan belajar pada kelas eksperimen lebih tinggi daripada kelas kontrol. Hal ini dibuktikan dengan nilai pretest dengan ketuntasan $30 \%$ menjadi $60 \%$ pada nilai posttestnya. Peningkatan nilai pretest pada kelas eksperimen dari presentase sebesar $5 \%$ naik sebesar $70 \%$ menjadi $75 \%$ presentase dari nilai posttest.

Selain penilaian kognitif (pengetahuan) berupa posttest, ketuntasan nilai siswa juga terlihat pada hasil afektif (sikap) dan psikomotorik (keterampilan) siswa. Pada nilai afektif kelas kontrol dan kelas ekperimen setelah dilakukan 2 kali pertemuan maka diperoleh hasil bahwa kelas kontrol pada pembelajaran 1 diperoleh rata-rata sebesar 75 dan pada pembelajaran 2 diperoleh rata-rata sebesar 80,4. Sedangkan pada kelas eksperimen diperoleh rata-rata nilai pada pertemuan 1 sebesar 76,7 dan pertemuan 2 sebesar 85,9. Presentase penilaian afektif (sikap) pada kelas kontrol sebesar 77,7\% sedangkan pada kelas eksperimen sebesar 81,3. Dapat diambil kesimpulan bahwa nilai rata-rata afektif kelas ekperimen lebih tinggi daripada kelas kontrol.

Perolehan rata -rata nilai psikomotorik (keterampilan) pada kelas ekperimen dan kelas kontrol juga dapat dilihat berdasatkan hasil analisis rata-rata nilai. Pada pertemuan 1 dan 2 di kelas kontrol diperoleh nilai 72,5 dan 82,1. Sehingga diperoleh rata-rata nilai psikomotorik kelas kontrol sebesar 77,3. Sedangkan pada pertemuan 1 dan 2 di kelas eksperimen diperoleh nilai 82,9 dan 88,3. Sehingga diperoleh rata-rata nilai psikomotorik kelas eksperimen sebesar 85,6. Dari kedua hasil analisis tersebut dapat disimpulkan bahwa nilai rata-rata kelas eksperimen lebih tinggi daripada kelas kontrol.

\section{Daftar Rujukan}

Azmi, Muhamad Khairul, Satutik Rahayu, Hikmawati. 2016. Pengaruh Model Problem Based Learning dengan Metode Eksperimen dan Diskusi Terhadap Hasil Belajar Fisika Ditinjau dari Sikap Ilmiah Siswa Kelas X MIPA SMA N 1 Mataram. Jurnal Pendidikan Fisika dan Teknologi Volume II No 2 Hal. 86-94. Tersedia Pada http://download.garuda.ristekdikti.go.id/article.php?article=917835\&val=14364\&title=Pengaruh \%20Model\%20Problem\%20Based\%20Learning\%20dengan\%20Metode\%20Eksperimen\%20dan \%20Diskusi\%20Terhadap\%20Hasil\%20Belajar\%20Fisika\%20Ditinjau\%20dari\%20Sikap\%20Ilmi ah\%20Siswa\%20Kelas\%20X\%20MIPA\%20\%20SMA\%20N\%201\%20Mataram. Diakses tanggal 18 Mei 2018.

Dewi, Erni Ratna. 2018. Metode Pembelajaran Modern dan Konvensional pada Sekolah Menengah Atas. Jurnal Ilmu Pendidikan, Keguruan, dan Pembelajaran Vol. 2 No. 1 Hal. 44-52. Tersedia Pada : https://ojs.unm.ac.id/pembelajar/article/view/5442. Diakses tanggal 18 Mei 2018.

Dewina, Sindy, Ondi Suganda, Rahma Widiantie. 2017. Pengaruh Model Pembelajaran Problem Based Learning (PBL) terhadap Kemampuan Menganalisis dan Keterampilan Berargumentasi Siswa pada Konsep Pencemaran Lingkungan di Kelas X. Jurnal Pendidikan dan Biologi Volume 9, Nomor 2 Hal. 46-54. Tersedia Pada : https://journal.uniku.ac.id/index.php/quagga/article/view/748. Diakses tanggal 18 Mei 2018.

Fauziah, Intan, Samsul Maarif, Trisna Roy Pradipta. 2018. Peningkatan Kemampuan Komunikasi Matematis dan Self Regulated Learning Siswa Melalui Model Problem Based Learning (PBL). Jurnal Analisa Vol. 4 No. 2 Hal. 90-98. Tersedia Pada : http://journal.uinsgd.ac.id/index.php/analisa/index. Diakses tanggal 18 Mei 2018.

Hosnan. 2016. Pendekatan Saintifik dan Kontektual dalam Pembelajaran Abad 21. Bogor: Ghalia Indonesia.

Ibrahim. 2017. Perpaduan Model Pembelajaran Aktif Konvensional (Ceramah) Dengan Cooperatif (Make A Match) untuk Meningkatkan Hasil Belajar Pendidikan Kewarganegaraan. Jurnal Ilmu Pendidikan Sosial, sains, dan Humaniora Vol. 3 No. 2, Hal. 199-211. Tersedia Pada : http://ejournal.uinsuska.ac.id/index.php/suaraguru/article/view/3597. Diakses tanggal 18 Mei 2018. 
Kunandar. 2014. Penilaian Autentik (Penilaian Hasil Belajar Peserta Didik Berdasatkn Kurikulum 2013): Suatu Pendekatan Praktis Disertai dengan Contoh. Jakarta: PT Raja Grafindo Persada.

Shoimin, Aris. 2014. 68 Model Pembelajaran Inovatif dalam Kuriklum 2013. Yogyakarta: Ar-ruzz media.

Sianturi, Aprilita, Tetty Natalia Sipayung, dan Frida Marta Argareta Simorangkir. 2018. Pengaruh Model Problem Based Learning (PBL) terhadap Kemampuan Berpikir Kritis Matematis Siswa SMPN 5 Sumbul. UNION: Jurnal Pendidikan Matematika Vol 6 No 1 Hal. 29-42. Tersedia Pada : http://jurnal.ustjogja.ac.id/index.php/union/article/view/2082. Diakses tanggal 18 Mei 2018.

Sugiarti, Arif, Mursalin. 2018. Pembelajaran Abad 21 di SD. Prosiding Seminar dan Diskusi Nasional Pendidikan Dasar 2018. http://journal. unj. ac. id /unj /index. Php /psdpd /article /download /10184 /6600/. Diakses tanggal 17 Mei 2019.

Wijaya, Sudjimat, Nyoto. 2018. Transformasi Pendidikan Abad 21 Sebagai Tuntutan Pengembangan Sumber Daya Manusia di Era Global. Prosiding Seminar Nasional Pendidikan Matematika 2016. http://repository.unikama.ac.id/840/32/263-

278\%20TRANSFORMASI\%20PENDIDIKAN\%20ABAD\%2021\%20SEBAGAI\%20TUNTUTAN\%20PE NGEMBANGAN\%20SUMBER\%20DAYA\%20MANUSIA\%20DI\%20ERA\%20GLOBAL.pdf. Diakses tanggal 18 Mei 2018. 